\title{
EFIKASI HERBISIDA METIL METSULFURON UNTUK MENGENDALIKAN GULMA PADA TANAMAN KELAPA SAWIT (Elaeis guineensis Jacq.) MENGHASILKAN
}

\author{
Virgio Koriyando, Herry Susanto, Sugiatno \& Hidayat Pujisiswanto \\ Jurusan Agroteknologi, Fakultas Pertanian Universitas Lampung \\ Jl. Prof. Dr. Soemantri Brodjonegoro no. 1 Bandar Lampung 35145 \\ Email: virgiokoriyando@gmail.com
}

\begin{abstract}
ABSTRAK
Salah satu faktor yang harus diperhatikan dalam meningkatkan produksi tanaman kelapa sawit adalah faktor lingkungan terutama masalah keberadaan gulma yang dapat menekan pertumbuhan dan hasil. Aplikasi herbisida merupakan pengendalian gulma secara kimiawi dan herbisida metil metsulfuron berpotensi efektif mengendalikan gulma pada piringan tanaman kelapa sawit. Penelitian bertujuan untuk mengetahui pengaruh herbisida metil metsulfuron terhadap gulma total dan gulma dominan pada lahan tanaman kelapa sawit menghasilkan, dosis herbisida metil metsulfuron yang efektif untuk mengendalikan gulma total dan gulma dominan pada lahan tanaman kelapa sawit menghasilkan, dan perubahan komunitas gulma akibat perlakuan herbisida metil metsulfuron pada lahan tanaman kelapa sawit menghasilkan. Penelitian dilakukan di areal perkebunan kelapa sawit di Desa Mujimulyo, Natar, Lampung Selatan dan di Laboratorium Gulma, Fakultas Pertanian, Universitas Lampung, Bandar lampung. Penelitian menggunakan rancangan kelompok teracak sempurna (RKTS) yang terdiri atas 7 perlakuan yaitu dosis metil metsulfuron 15,75, 21,00, 26,25, dan 31,50 $\mathrm{g} \mathrm{ha}^{-1}$, metil metsulfuron pembanding (20,00 $\left.\mathrm{g} \mathrm{ha}^{-1}\right)$, penyiangan mekanis, dan tanpa pengendalian (kontrol). Penelitian diulang 4 kali dan setiap satuan percobaan terdiri atas 3 piringan tanaman kelapa sawit. Homogenitas ragam diuji dengan uji Bartlet dan aditivitas data diuji dengan uji Tukey. Data dianalisis ragam dan perbedaan nilai tengah diuji dengan Uji BNT pada taraf nyata 5\%. Hasil penelitian menunjukan bahwa aplikasi herbisida metil metsulfuron dosis 15,75 - 31,50 $\mathrm{g} \mathrm{ha}^{-1}$ efektif mengendalikan gulma total pada 4, 8, dan 12 MSA. Herbisida metil metsulfuron dosis 15,75 - 31,50 $\mathrm{g} \mathrm{ha}^{-1}$ efektif mengendalikan Ageratum conyzoides dan Synedrella nodiflora pada 8 dan 12 MSA, Axonopus compressus pada 12 MSA, dan Cyperus kyllingia pada 8 MSA dan terjadi perubahan komunitas gulma akibat aplikasi herbisida metil metsulfuron.
\end{abstract}

Kata kunci: kelapa sawit, gulma, herbisida metil metsulfuron

\section{PENDAHULUAN}

Tanaman kelapa sawit mempunyai nilai ekonomi yang sangat penting bagi kehidupan manusia yang dapat memenuhi kebutuhan akan minyak nabati. Tanaman lain yang dapat digunakan sebagai sumber minyak nabati adalah kelapa dan kacang kedelai. Namun demikian kelapa sawit merupakan penyumbang minyak nabati terbesar di dunia. Manfaat buah kelapa sawit sangat beragam. Banyak industri yang menggunakan kelapa sawit sebagai bahan bakunya, misalnya industri makanan, kosmetik, dan lain-lain (Syamsulbahri, 1996).

Beberapa kerugian yang diakibatkan oleh gulma seperti menurunkan kemampuan produksi kelapa sawit, mengganggu manajemen kebun, menyebabkan naiknya biaya usaha pertanian, mengurangi fungsi saluran drainase dan jalan yang disebabkan oleh gulma, dan pemborosan air akibat penguapan yang lebih cepat
(Effendi, 2011). Selain terjadi penurunan produksi akibat gulma pada tanaman kelapa sawit juga dapat mengganggu kegiatan budidaya tanaman seperti pemupukan, panen, dan pemungutan buah jatuh (Risza, 1994).

Gulma yang tumbuh di areal tanaman kelapa sawit umumnya sangat beragam baik jenis maupun spesiesnya. Gulma yang tumbuh di areal pertanaman menghasilkan tidak sebanyak gulma yang tumbuh pada tanaman belum menghasilkan karena semakin sedikitnya intensitas cahaya matahari yang diteruskan kepermukaan tanah 1,32\% (Purwasih, 2013). Baik gulma maupun tanaman mempunyai kebutuhan dasar yang sama untuk pertumbuhan dan perkembangan yang normal. Kebutuhan tersebut berupa unsur hara, air, cahaya, ruang tumbuh, dan $\mathrm{CO}_{2}$. Persaingan akan terjadi jika unsur-unsur yang dibutuhkan tersebut tersedia dalam jumlah yang terbatas. Hal ini akan mengakibatkan 
kebutuhan tanaman tidak terpenuhi secara optimal sehingga dapat menurunkan produksi tanaman budidaya (Moenandir, 1993).

Pengendalian gulma yang umum dilakukan di perkebunan kelapa sawit, yaitu secara kimiawi dan manual. Penyiangan piringan tanaman kelapa sawit secara manual dengan memotong rumputan di piringan tanaman dengan radius 2-2,5 meter. Pengendalian gulma diperkebunan kelapa sawit dilakukan pada dua tempat, yaitu dipiringan dan gawangan. Ada tiga golongan gulma yang perlu dikendalikan, yaitu daun lebar, rumput dan teki (Pahan, 2006). Pengendalian gulma pada piringan bertujuan untuk mengurangi persaingan antara tanaman utama dan gulma serta mampermudah pekerjaan panen, pemupukan dan pekerjaan pengawasan lainnya. Biasanya pengendalian gulma umum dilakukan jika kondisi penutupan gulma telah mencapai $30 \%$ sampai $50 \%$ pada piringan kelapa sawit (Barus, 2003). Tujuan penelitian adalah sebagai untuk mengetahui efektivitas herbisida metil metsulfuron terhadap pengendalian pertumbuhan gulma total dan gulma dominan pada piringan tanaman kelapa sawit menghasilkan, untuk menentukan dosis herbisida metil metsulfuron yang efektif untuk mengendalikan gulma total dan gulma dominan pada piringan tanaman kelapa sawit menghasilkan, dan untuk mempelajari perubahan komunitas jenis gulma setelah aplikasi herbisida metil metsulfuron pada piringan tanaman kelapa sawit menghasilkan.

\section{BAHAN DAN METODE}

Penelitian dilakukan di areal perkebunan kelapa sawit Desa Mujimulyo, Kecamatan Natar, Lampung Selatan dan di Laboratorium Gulma, Fakultas Pertanian, Universitas Lampung dari bulan Maret sampai dengan Mei 2010.

Alat yang digunakan dalam penelitian ini adalah knapsacksprayer semi automatic Matabi Super 16, nozel T-jet berwarna merah, gelas ukur, ember, kuadran, meteran, kantung plastik, amplop kertas, oven, dan timbangan. Bahan yang digunakan dalam penelitian ini antara lain areal tanaman kelapa sawit yang telah menghasilkan, herbisida metil metsulfuron (Juru 21 WG dan Ally 20 WDG) dan air sebagai pelarut.

Pemilihan lokasi yang digunakan untuk penelitian ini adalah areal perkebunan kelapa sawit milik petani dengan persentase penutupan gulma pada piringan mencapai $75 \%$. Petak perlakuan ditentukan sebanyak 7 petak dengan 4 ulangan. Setiap satuan percobaan terdiri atas 3 piringan tanaman kelapa sawit. Masingmasing piringan tanaman kelapa sawit berdiameter 3 meter. Jarak antarsatuan percobaan adalah satu tanaman kelapa sawit. Jarak tanam kelapa sawit adalah $9 \mathrm{~m} \times 9 \mathrm{~m} \times 9 \mathrm{~m}$ (sistem segitiga sama sisi). Sebelum aplikasi herbisida, terlebih dahulu dilakukan kalibrasi dengan metode luas untuk menentukan volume semprot. Berdasarkan hasil kalibrasi diperoleh volume semprot 480 liter/ha. Dosis yang telah ditentukan untuk masingmasing petak perlakuan dilarutkan ke dalam air sebanyak hasil kalibrasi kemudian disemprotkan secara merata pada piringan tanaman kelapa sawit. Pengambilan sampel gulma dilakukan sebanyak empat kali yaitu: sebelum aplikasi, 4, 8, dan 12 minggu setelah aplikasi (MSA). Gulma diambil menggunakan metode luas dengan kuadran berukuran $0,5 \mathrm{~m}$ x 0,5 m pada dua titik pengambilan yang berbeda untuk setiap petak percobaan dan setiap waktu pengambilan sampel.

Pengamatan persentase keracunan gulma dilakukan pada 2, 4, 6, dan 8 MSA secara visual pada setiap perlakuan. Persentase penutupan gulma adalah luas permukaan tanah yang ditutupi oleh gulma di lokasi yang diamati. Pengamatan persentase penutupan gulma dilakukan dengan mengamati secara visual berapa luas permukaan tanah yang ditutupi gulma dan dilakukan pada $0,4,6,8$, dan 12 MSA. Pengambilan contoh gulma untuk data biomasa, kerapatan dan frekuensi dilakukan sebelum aplikasi herbisida, dimaksudkan untuk menganalisis vegetasi gulma. Bobot kering gulma total diamati saat 4, 8, dan 12 MSA. Gulma yang telah dipotong dipilah menurut spesiesnya dan dikeringkan menggunakan oven pada suhu $80^{\circ} \mathrm{C}$ selama $2 \times 24$ jam, kemudian ditimbang untuk mengetahui bobot keringnya.

\section{HASIL DAN PEMBAHASAN}

Pengamatan persentase keracunan gulma dilakukan secara visual dengan melihat gejala keracunan pada gulma seperti terjadinya perubahan kondisi fisik gulma. Nilai persentase keracunan gulma tersebut dapat dilihat pada Tabel 1. Perlakuan herbisida metil metsulfuron (Juru $21 \mathrm{WG}$ ) dengan dosis 15,75, 21, 26,25, dan 31,5 $\mathrm{g} \mathrm{ha}^{-1}$ efektif meracuni gulma total di lahan kelapa sawit pada 2, 4, 6, dan 8 MSA. Berdasarkan data tersebut (Tabel 1), metil metsulfuron dengan dosis 26,25 $\mathrm{g} \mathrm{ha}^{-1}$ (Juru $21 \mathrm{WG)} \mathrm{memiliki} \mathrm{kemampuan}$ meracuni gulma yang tertinggi. Akan tetapi, herbisida yang paling efektif digunakan dalam mengendalikan gulma adalah Ally $20 \mathrm{WDG}$ dengan dosis $20 \mathrm{~g} \mathrm{ha}^{-1}$, karena herbisida ini memiliki kemampuan meracuni gulma yang sama dengan Juru $21 \mathrm{WG}$ (dosis 26,25 dan $\left.31,5 \mathrm{~g} \mathrm{ha}^{-1}\right)$ dan dengan dosis yang lebih rendah $(20 \mathrm{~g}$ ha $\left.^{-1}\right)$. Herbisida berbahan aktif metil metsulfuron merupakan herbisida yang bersifat sitemik dan selektif 
terhadap gulma. Cara kerja herbisida ini dengan menghambat sintesis asam amino yang menyebabkan pertumbuhan dan perkembangan sel berhenti (Tomlin, 2004). Data persentase penutupan gulma total menunjukkan bahwa perlakuan herbisida metil metsulfuron (Juru $21 \mathrm{WG)}$ ) pada dosis 15,75, 21, 26,25, dan $31,5 \mathrm{~g} \mathrm{ha}^{-1}$ efektif menekan penutupan gulma total pada 4, 6, 8 dan 12 MSA (Tabel 2). Dari table tersebut dapat dilihat bahwa nilai penutupan yang berbeda bila dibandingkan dengan kontrol. Hal ini membuktikan bahwa herbisida metil metsulfuron yang diaplikasikan mampu menekan pertumbuhan gulma. Kemampuan herbisida metil metsulfuron dalam menekan penutupan gulma hampir sama antara dosis yang satu dengan dosis yang lain. Pada 4 MSA, persentase penutupan gulma terendah diperoleh pada dosis $31,50 \mathrm{~g} \mathrm{ha}^{-1}$. Hasil yang serupa juga diperoleh pada 6, 8, dan 12 MSA. Berdasarkan data pada Tabel 3 menunjukkan bahwa pada berbagai dosis herbisida metil metsulfuron mampu mengendalikan gulma total pada 12 MSA. Hal ini ditunjukan oleh bobot kering gulma total yang lebih rendah dibandingkan dengan kontrol. Hal serupa juga disampaikan oleh Alfredo (2012) bahwa bobot kering gulma yang lebih rendah dibandingkan dengan kontrol.

Tabel 1.Pengaruh dosis metilmetsufuron dan penyiangan mekanis pada keracunan gulma total.

\begin{tabular}{|c|c|c|c|c|c|c|c|c|}
\hline \multirow{2}{*}{ Perlakuan } & \multicolumn{2}{|c|}{$2 \mathrm{MSA}$} & \multicolumn{2}{|c|}{$4 \mathrm{MSA}$} & \multicolumn{2}{|c|}{$6 \mathrm{MSA}$} & \multicolumn{2}{|c|}{$8 \mathrm{MSA}$} \\
\hline & \multicolumn{8}{|c|}{ - } \\
\hline Metilmetsufuron $15,75 \mathrm{~g} / \mathrm{ha}(\mathrm{A})$ & 42,5 & a & 47,5 & $\mathrm{~b}$ & 55,0 & $\mathrm{~b}$ & 67,5 & $\mathrm{~b}$ \\
\hline Metilmetsufuron $21,00 \mathrm{~g} / \mathrm{ha}(\mathrm{A})$ & 40,0 & a & 47,5 & $\mathrm{~b}$ & 55,0 & $\mathrm{~b}$ & 65,0 & $\mathrm{~b}$ \\
\hline Metilmetsufuron $26,25 \mathrm{~g} / \mathrm{ha}(\mathrm{A})$ & 51,2 & $\mathrm{a}$ & 60,0 & $a b$ & 67,5 & $a b$ & 76,2 & a \\
\hline Metilmetsufuron $31,50 \mathrm{~g} / \mathrm{ha}(\mathrm{A})$ & 55,0 & $\mathrm{a}$ & 68,7 & $\mathrm{a}$ & 70,0 & $\mathrm{a}$ & 80,0 & $\mathrm{a}$ \\
\hline Metilmetsufuron $20,00 \mathrm{~g} / \mathrm{ha}(\mathrm{B})$ & 52,5 & a & 67,5 & $\mathrm{a}$ & 70,0 & $\mathrm{a}$ & 78,7 & a \\
\hline Pen yiangan Mekanis & 0,0 & $\mathrm{~b}$ & 0,0 & $\mathrm{c}$ & 0,0 & $\mathrm{c}$ & 0,0 & $\mathrm{c}$ \\
\hline Kontrol & 0,0 & $\mathrm{~b}$ & 0,0 & $\mathrm{c}$ & 0,0 & $\mathrm{c}$ & 0,0 & $\mathrm{c}$ \\
\hline BNT $5 \%$ & 15,9 & & 14,3 & & 14,2 & & 8,1 & \\
\hline
\end{tabular}

Keterangan : Angka yang diikuti dengan huruf yang sama dalam setiap kolom tidak berbeda nyata pada taraf $5 \%$ uji BNT. (A) : Juru 21 WG, (B) : Ally 20 WDG.

Tabel 2. Pengaruh metilmetsufuron dan penyiangan mekanis pada penutupan gulma

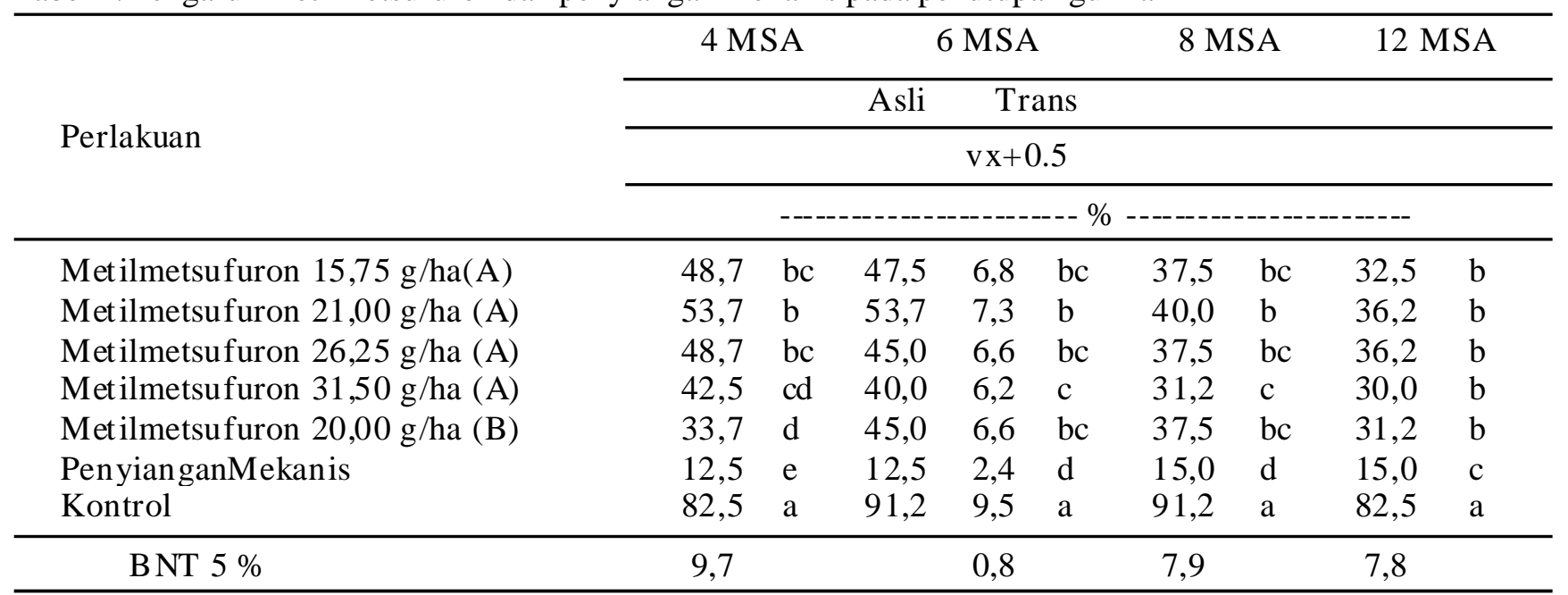

Keterangan : Angka yang diikuti dengan huruf yang sama dalam setiap kolom tidak berbeda nyata pada taraf 5\% uji BNT. (A) : Juru $21 \mathrm{WG}$ (B) : Ally $20 \mathrm{WDG}$. 
Metil metsulfuron bersifat sistemik, diabsorbsi oleh akar dan daun, serta ditranslokasikan secara akropetal dan basipetal. Gulma yang peka akan berhenti tumbuh hampir segera setelah aplikasi dan akan mati dalam 7 21 hari (Djojosumarto, 2008).

Berdasarkan data bobot kering gulma Ageratum conyzoides, perlakuan herbisida metil metsulfuron dan penyiangan mekanis mampu mengendalikan gulma Ageratum conyzoides pada 8 dan 12 MSA (Tabel 4). Berdasarkan data bobot kering gulma Lantana camara menunjukkan bahwa semua perlakuan dosis herbisida metil metsulfuron yang diuji tidak memiliki tingkat daya kendali gulma Lantana camara pada 4 sampai $12 \mathrm{MSA}$ (Tabel 5). Perlakuan metil metsulfuron pada 15,75, 21, 26,25, dan 31,5 $\mathrm{g} \mathrm{ha}^{-1}$ mampu mengendalikan gulma Synedrella nodiflora pada 8 dan 12 MSA (Tabel 6). Perlakuan metil metsulfuron pada dosis 15,75, 21, 26,25, dan $31,5 \mathrm{~g} \mathrm{ha}^{-1}$ mampu mengendalikan gulma Axonopus compressus pada 12 MSA(Tabel 7). Data bobot kering gulma Cyperus kyllingia menunjukkan bahwa gulma

Tabel 3. Pengaruh metilmetsufuron dan penyiangan mekanis terhadap bobot kering gulma total

\begin{tabular}{|c|c|c|c|c|c|c|}
\hline \multirow{3}{*}{$\begin{array}{l}\text { Perlakuan } \\
\text { Metilmetsufuron } 15,75 \mathrm{~g} / \mathrm{ha} \text { (A) }\end{array}$} & \multicolumn{2}{|c|}{$4 \mathrm{MSA}$} & \multicolumn{2}{|c|}{$8 \mathrm{MSA}$} & \multicolumn{2}{|c|}{$12 \mathrm{MSA}$} \\
\hline & \multicolumn{6}{|c|}{ - } \\
\hline & 18,20 & $\mathrm{a}$ & 9,3 & $a b$ & 1,04 & $\mathrm{c}$ \\
\hline Metilmetsufuron $21,00 \mathrm{~g} / \mathrm{ha}$ (A) & 16,50 & $\mathrm{a}$ & 8,1 & $a b$ & 1,68 & $\mathrm{~cd}$ \\
\hline Metilmetsufuron $26,25 \mathrm{~g} / \mathrm{ha}$ (A) & 13,89 & $a b$ & 6,4 & $\mathrm{~cd}$ & 1,27 & $\mathrm{~cd}$ \\
\hline Metilmetsufuron $31,50 \mathrm{~g} / \mathrm{ha}$ (A) & 5,96 & $\mathrm{~cd}$ & 3,0 & $\mathrm{~cd}$ & 2,42 & $\mathrm{~cd}$ \\
\hline Metilmetsufuron $20,00 \mathrm{~g} / \mathrm{ha}(\mathrm{B})$ & 12,36 & $a b$ & 8,7 & $a b$ & 3,22 & $\mathrm{c}$ \\
\hline PenyianganMekanis & 0,37 & $\mathrm{e}$ & 1,0 & $\mathrm{e}$ & 1,60 & $\mathrm{~cd}$ \\
\hline Kontrol & 20,47 & $\mathrm{a}$ & 13,4 & $\mathrm{a}$ & 7,07 & $\mathrm{a}$ \\
\hline
\end{tabular}

Keterangan : Angka yang diikuti dengan huruf yang sama dalam setiap kolom tidak berbeda nyata pada taraf 5\% uji BNT. (A) : Juru 21 WG, (B) : Ally 20 WDG.

Tabel 4. Pengaruh metilmetsufuron dan penyiangan mekanis terhadap bobot kering gulmaAgeratum conyzoides

\begin{tabular}{|c|c|c|c|c|c|c|c|}
\hline \multirow{4}{*}{ Perlakuan } & \multicolumn{2}{|c|}{$4 \mathrm{MSA}$} & \multicolumn{3}{|c|}{$8 \mathrm{MSA}$} & \multicolumn{2}{|c|}{$12 \mathrm{MSA}$} \\
\hline & Asli & \multirow{2}{*}{$\frac{\text { Trans }}{\mathrm{v}(\mathrm{x}+0.5}$} & Asli & \multicolumn{2}{|c|}{ Trans } & & \\
\hline & & & & \multicolumn{2}{|c|}{$\mathrm{vvx}+0.5$} & & \\
\hline & \multicolumn{7}{|c|}{ - g/0,5m² } \\
\hline Metilmetsufuron $15,75 \mathrm{~g} / \mathrm{ha}(\mathrm{A})$ & 1,95 & 0,41 & 0,00 & 0,50 & $\mathrm{~b}$ & 0,00 & $\mathrm{~b}$ \\
\hline Metilmetsufuron $21,00 \mathrm{~g} / \mathrm{ha}(\mathrm{A})$ & 0,77 & 0,53 & 0,00 & 0,50 & $\mathrm{~b}$ & 0,00 & $\mathrm{~b}$ \\
\hline Metilmetsufuron $26,25 \mathrm{~g} / \mathrm{ha} \mathrm{(A)}$ & 0,14 & 0,21 & 0,00 & 0,50 & $\mathrm{~b}$ & 0,00 & $\mathrm{~b}$ \\
\hline Metilmetsufuron $31,50 \mathrm{~g} / \mathrm{ha}(\mathrm{A})$ & 0,05 & 0,25 & 0,00 & 0,50 & $\mathrm{~b}$ & 0,00 & $\mathrm{~b}$ \\
\hline Metilmetsufuron $20,00 \mathrm{~g} / \mathrm{ha}(\mathrm{B})$ & 0,00 & 0,00 & 0,00 & 0,50 & $\mathrm{~b}$ & 0,00 & $\mathrm{~b}$ \\
\hline PenyianganMekanis & 0,00 & 0,00 & 0,00 & 1,23 & $\mathrm{a}$ & 0,55 & a \\
\hline Kontrol & 2,46 & 0,95 & 1,63 & 1,28 & $\mathrm{a}$ & 0,82 & $\mathrm{a}$ \\
\hline BNT $5 \%$ & & 0,76 & & 0,32 & & 0,38 & \\
\hline
\end{tabular}

Keterangan : Angka yang diikuti dengan huruf yang sama dalam setiap kolom tidak berbeda nyata pada taraf $5 \%$ uji BNT. (A) : Juru 21 WG, (B) : Ally 20 WDG. 
Tabel 5. Pengaruh metilmetsufuron dan penyiangan mekanis terhadap bobot kering gulma Lantana camara

\begin{tabular}{|c|c|c|c|c|c|c|}
\hline \multirow{2}{*}{ Perlakuan } & \multicolumn{2}{|c|}{$4 \mathrm{MSA}$} & \multicolumn{2}{|c|}{$8 \mathrm{MSA}$} & \multicolumn{2}{|c|}{$12 \mathrm{MSA}$} \\
\hline & \multicolumn{6}{|c|}{ - } \\
\hline Metilmetsufuron $15,75 \mathrm{~g} / \mathrm{ha} \mathrm{A}$ ) & 1,66 & a & 0,00 & $\mathrm{a}$ & 0,00 & a \\
\hline Metilmetsufuron $21,00 \mathrm{~g} / \mathrm{ha}(\mathrm{A})$ & 0,32 & a & 0,00 & a & 0,00 & a \\
\hline Metilmetsufuron $26,25 \mathrm{~g} / \mathrm{ha}(\mathrm{A})$ & 0,04 & $\mathrm{a}$ & 0,00 & $\mathrm{a}$ & 0,00 & a \\
\hline Metilmetsufuron $31,50 \mathrm{~g} / \mathrm{ha}(\mathrm{A})$ & 0,07 & $\mathrm{a}$ & 0,00 & $\mathrm{a}$ & 0,00 & $\mathrm{a}$ \\
\hline Metilmetsufuron $20,00 \mathrm{~g} / \mathrm{ha}(\mathrm{B})$ & 0,00 & $\mathrm{a}$ & 0,00 & $\mathrm{a}$ & 0,00 & a \\
\hline PenyianganMekanis & 0,00 & $\mathrm{a}$ & 0,00 & $\mathrm{a}$ & 0,00 & $\mathrm{a}$ \\
\hline Kontrol & 2,40 & $\mathrm{a}$ & 2,40 & $\mathrm{a}$ & 2,42 & $\mathrm{a}$ \\
\hline BNT $5 \%$ & 2,94 & & 2,47 & & 2,46 & \\
\hline
\end{tabular}

Keterangan : Angka yang diikuti dengan huruf yang sama dalam setiap kolom tidak berbeda nyata pada taraf 5\% uji BNT. (A) : Juru 21 WG, (B) : Ally 20 WDG.

Tabel 6. Pengaruh metilmetsufuron dan penyiangan mekanis bobot kering gulma Synedrella nodiflora

\begin{tabular}{|c|c|c|c|c|c|c|}
\hline \multirow[b]{2}{*}{ Perlakuan } & \multicolumn{2}{|c|}{$4 \mathrm{MSA}$} & \multicolumn{2}{|c|}{$8 \mathrm{MSA}$} & \multicolumn{2}{|c|}{$12 \mathrm{MSA}$} \\
\hline & \multicolumn{6}{|c|}{ - } \\
\hline Metilmetsufuron $15,75 \mathrm{~g} / \mathrm{ha} \mathrm{A}$ ) & 2,16 & a & 0,01 & $\mathrm{~b}$ & 0,00 & b \\
\hline Metilmetsufuron $21,00 \mathrm{~g} / \mathrm{ha}(\mathrm{A})$ & 0,11 & $\mathrm{~b}$ & 0,00 & $\mathrm{~b}$ & 0,00 & b \\
\hline Metilmetsu furon $26,25 \mathrm{~g} / \mathrm{ha}(\mathrm{A})$ & 0,11 & $\mathrm{~b}$ & 0,00 & $\mathrm{~b}$ & 0,00 & $\mathrm{~b}$ \\
\hline Metilmetsufuron $31,50 \mathrm{~g} / \mathrm{ha}(\mathrm{A})$ & 0,07 & $\mathrm{~b}$ & 0,00 & $\mathrm{~b}$ & 0,00 & $\mathrm{~b}$ \\
\hline Met ilmetsu furon $20,00 \mathrm{~g} / \mathrm{ha}$ (B) & 0,10 & $\mathrm{~b}$ & 0,00 & $\mathrm{~b}$ & 0,00 & $\mathrm{~b}$ \\
\hline PenyianganMekanis & 0,02 & $\mathrm{~b}$ & 0,00 & $\mathrm{~b}$ & 0,00 & $\mathrm{~b}$ \\
\hline Kontrol & 0,83 & $\mathrm{~b}$ & 0,96 & $\mathrm{a}$ & 0,33 & $\mathrm{a}$ \\
\hline BNT $5 \%$ & 1,28 & & 0,48 & & 0,22 & \\
\hline
\end{tabular}

Keterangan : Angka yang diikuti dengan huruf yang sama dalam setiap kolom tidak berbeda nyata pada taraf $5 \%$ uji BNT. (A) : Juru 21 WG, (B) : Ally 20 WDG.

Tabel 7. Pengaruh metilmetsufuron dan penyiangan mekanis terhadap bobot kering gulma Axonopus compresus

\begin{tabular}{|c|c|c|c|c|c|c|}
\hline \multirow{3}{*}{$\begin{array}{l}\text { Perlakuan } \\
\text { Metilmetsufuron } 15,75 \mathrm{~g} / \mathrm{ha} \mathrm{(A)}\end{array}$} & \multicolumn{2}{|c|}{$4 \mathrm{MS}$ A } & \multicolumn{2}{|c|}{$8 \mathrm{MSA}$} & \multicolumn{2}{|c|}{$12 \mathrm{MSA}$} \\
\hline & \multicolumn{6}{|c|}{ 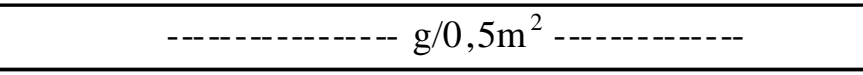 } \\
\hline & 7,58 & $\mathrm{ab}$ & 8,40 & $\mathrm{a}$ & 0,84 & $\mathrm{~b}$ \\
\hline Metilmetsufuron $21,00 \mathrm{~g} / \mathrm{ha}(\mathrm{A})$ & 10,96 & $\mathrm{~b}$ & 7,72 & $\mathrm{a}$ & 1,82 & $\mathrm{~b}$ \\
\hline Metilmetsufuron $26,25 \mathrm{~g} / \mathrm{ha}$ (A) & 11,03 & $\mathrm{~b}$ & 6,42 & $a b$ & 1,22 & $\mathrm{~b}$ \\
\hline Metilmetsufuron $31,50 \mathrm{~g} / \mathrm{ha}$ (A) & 4,25 & $\mathrm{ab}$ & 3,09 & $a b$ & 2,42 & $\mathrm{~b}$ \\
\hline Metilmetsufuron $20,00 \mathrm{~g} / \mathrm{ha}(\mathrm{B})$ & 11,56 & a & 8,36 & a & 2,87 & $\mathrm{~b}$ \\
\hline PenyianganMekan is & 0,32 & $\mathrm{~b}$ & 0,92 & $\mathrm{~b}$ & 0,95 & $\mathrm{~b}$ \\
\hline Kontrol & 9,00 & $a b$ & 6,55 & $a b$ & 5,83 & $\mathrm{a}$ \\
\hline BNT $5 \%$ & 5,03 & & 5,87 & & 2,39 & \\
\hline
\end{tabular}

Keterangan : Angka yang diikuti dengan huruf yang sama dalam setiap kolom tidak berbeda nyata pada taraf 5\% uji BNT. (A) : Juru 21 WG, (B) : Ally 20 WDG. 
Tabel 8. Pengaruh metilmetsufuron dan penyiangan mekanis terhadap bobot kering gulma Cyperus kylingia

\begin{tabular}{|c|c|c|c|c|c|c|}
\hline \multirow{2}{*}{ Perlakuan } & \multicolumn{2}{|c|}{$4 \mathrm{MSA}$} & \multicolumn{2}{|c|}{$8 \mathrm{MSA}$} & \multicolumn{2}{|c|}{$12 \mathrm{MSA}$} \\
\hline & \multicolumn{6}{|c|}{----------- g/0,5m² } \\
\hline Metilmetsufuron $15,75 \mathrm{~g} / \mathrm{ha} \mathrm{(A)}$ & 1,93 & $a b c$ & 0,92 & $a b$ & 0,00 & $\mathrm{a}$ \\
\hline Metilmetsufuron $21,00 \mathrm{~g} / \mathrm{ha}(\mathrm{A})$ & 4,29 & $\mathrm{a}$ & 0,43 & $\mathrm{c}$ & 0,00 & a \\
\hline Metilmetsufuron $26,25 \mathrm{~g} / \mathrm{ha}$ (A) & 2,02 & $\mathrm{abc}$ & 0,02 & $\mathrm{c}$ & 0,02 & $\mathrm{a}$ \\
\hline Metilmetsufuron $31,50 \mathrm{~g} / \mathrm{ha}(\mathrm{A})$ & 1,50 & $a b c$ & 0,00 & $\mathrm{c}$ & 0,00 & a \\
\hline Metilmetsufuron $20,00 \mathrm{~g} / \mathrm{ha}(\mathrm{B})$ & 0,47 & $\mathrm{~cd}$ & 0,37 & $\mathrm{c}$ & 0,00 & $\mathrm{a}$ \\
\hline Pen yian ganMekanis & 0,00 & $\mathrm{e}$ & 0,16 & $\mathrm{c}$ & 0,09 & $\mathrm{a}$ \\
\hline Kontrol & 2,97 & $a b$ & 1,77 & $\mathrm{a}$ & 0,08 & $\mathrm{a}$ \\
\hline BNT $5 \%$ & 2,87 & & 1,02 & & 0,15 & \\
\hline
\end{tabular}

Keterangan : Angka yang diikuti dengan huruf yang sama dalam setiap kolom tidak berbeda nyata pada taraf 5\% uji BNT. (A) : Juru $21 \mathrm{WG}$, (B) : Ally $20 \mathrm{WDG}$.

Tabel 9. Nilai koefisien komunitas gulma

\begin{tabular}{|c|c|c|c|}
\hline \multirow{2}{*}{ Perbandingan } & 4 MSA & $8 \mathrm{MSA}$ & $12 \mathrm{MSA}$ \\
\hline & \multicolumn{3}{|c|}{ 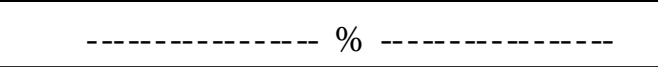 } \\
\hline Metilmetsufuron $15,75 \mathrm{~g} / \mathrm{ha}$ vs Kontrol & 35 & 26 & 46 \\
\hline Metilmetsufuron $21,00 \mathrm{~g} / \mathrm{ha}$ vs Kontrol & 38 & 28 & 43 \\
\hline Metilmetsufuron $26,25 \mathrm{~g}$ /ha vs Kontrol & 40 & 30 & 44 \\
\hline Metilmetsufuron $31,50 \mathrm{~g} / \mathrm{ha}$ vs Kontrol & 50 & 35 & 42 \\
\hline Metilmetsufuron $20,00 \mathrm{~g} / \mathrm{ha}$ vs Kontrol & 42 & 28 & 38 \\
\hline
\end{tabular}

tidak dapat terkendali pada semua perlakuan metil metsulfuron yang diuji pada 4 dan 12 MSA. Perlakuan metil metsulfuron $21-31,5 \mathrm{~g} \mathrm{ha}^{-1}$ mampu mengendalikan gulma teki pada 8 MSA (Tabel 8). Herbisida metil metsulfuron bersifat sistemik untuk mengendalikan gulma daun lebar sehingga kurang mampu untuk mengendalikan gulma teki. Gulma yang peka akan berhenti tumbuh hampir segera setelah aplikasi dan akan mati dalam 7 - 21 hari (Djojosumarto, 2008). Perubahan komunitas gulma selalu terjadi pada pengamatan 4,8 dan 12 MSA, perubahan yang terjadi pada golongan gulma daun lebar menjadi golongan rumput dan teki. Perubahan komunitas gulma disebabkan semakin banyaknya gulma sasaran yang terkendali. Dari semua perlakuan perubahan komunitas tertinggi terjadi pada perlakuan metil metsulfuron $15,75 \mathrm{~g} \mathrm{ha}^{-1}$ yang terjadi pada 8 MSA yang memiliki nilai koefisiensi komunitas sebesar $26 \%$. Sedangkan perubahan komunitas terendah terdapat pada perlakuan metil metsulfuron dosis 31,5 $\mathrm{g} \mathrm{ha}^{-1}$ yang terjadi pada 4 MSA (Tabel 9).

\section{KESIMPULAN}

Penelitian yang telah dilakukan dapat disimpulkan bahwa herbisida metil metsulfuron dosis 15,75 - 31,50 $\mathrm{g} \mathrm{ha}^{-1}$ efektif mengendalikan pertumbuhan gulma total pada 4, 6, 8, dan 12 minggu setelah aplikasi (MSA). Herbisida metil metsulfuron dosis 15,75-31,50 $\mathrm{g} \mathrm{ha}^{-1}$ efektif mengendalikan gulma Ageratum conyzoides dan Synedrella nodiflora pada 8 dan 12 MSA, Axonopus compressus pada 12 MSA, dan Cyperus kyllingia pada 8 MSA. Herbisida metil metsulfuron mengakibatkan terjadinya perubahan komunitas gulma di piringan tanaman kelapa swit.

\section{SANWACANA}

Ucapan terima kasih kepada Ir. Dad Resiworo J. Sembodo, M.S. sebagai Penguji atas bantuan dan bimbingannya selama proses penelitian hingga pembuatan jurnal dan skripsi. 


\section{DAFTAR PUSTAKA}

Alfredo, N. 2012. Efikasi Herbisida Pratumbuh Metil Metsulfuron Tunggal dan Kombinasi dengan 2,4D, Ametrin, atau Diuron terhadap Gulma Pada Pertanaman Tebu (Saccharum officinarum L.) Lahan Kering. Agro Tropika. 17(1): 29- 34.

Barus. 2003. Pengendalian Gulma Di Perkebunan, Efektifitas dan Efisiensi Aplikasi Herbisida. Kanisius (Anggota IKAPI). Yogyakarta. $101 \mathrm{hlm}$.

Djojosumarto, P. 2008. Pestisida dan aplikasinya. PT Agromedia Pustaka. Tanggerang. $340 \mathrm{hlm}$.

Effendi, R. 2011. Buku Pintar Kelapa Sawit. Agromedia Pustaka. Jakarta Selatan. 296 hlm.

Moenandir, J. 1993. Persaingan Gulma dengan Tanaman Budidaya. Ilmu Gulma Buku III. PT Raja Grafindo Persada. Jakarta. 101 hlm.
Pahan. 2006. Panduan Lengkap Kelapa Sawit Manajemen Agribisnis dari Hulu Hingga Hilir. Niaga Swadaya. Bogor. 404 hlm.

Purwasih, S. 2013. Struktur Komunitas Gulma Pada Kebun Peremajaan Kelapa Sawit Di Lahan Gambut PT. Bumi Pratama Khatulistiwa (BPK) Kebun Raya.Sains Mahasiswa Pertanian Tanjungpura. 2(2): 10 - $20 \mathrm{hlm}$.

Risza, S. 1994. Kelapa Sawit Upaya Peningkatan Produktivitas. Kanisius. Jakarta. $186 \mathrm{hlm}$.

Syamsulbahri.1996. Bercocok Tanam Tanaman Perkebunan Tahunan. Universitas Gajah Mada. Yogyakarta. $177 \mathrm{hlm}$.

Tomlin, CDS. 2004. The Pesticide Manual volume 3.0. British Crop Protection Council. Inggris. 1606 p. 